University of Nebraska - Lincoln

DigitalCommons@University of Nebraska - Lincoln

\title{
A crop water stress index and time threshold for automatic irrigation scheduling of grain sorghum
}

\author{
Susan A. O'Shaughnessy \\ USDA-ARS, Susan.OShaughnessy@ars.usda.gov \\ Steven R. Evett \\ USDA-ARS, steve.evett@ars.usda.gov \\ Paul D. Colaizzi \\ USDA-ARS, Paul.Colaizzi@ARS.USDA.GOV \\ Terry A. Howell \\ USDA-ARS, Terry.Howell@ars.usda.gov
}

Follow this and additional works at: https://digitalcommons.unl.edu/usdaarsfacpub

O'Shaughnessy, Susan A.; Evett, Steven R.; Colaizzi, Paul D.; and Howell, Terry A., "A crop water stress index and time threshold for automatic irrigation scheduling of grain sorghum" (2012). Publications from USDA-ARS / UNL Faculty. 1825.

https://digitalcommons.unl.edu/usdaarsfacpub/1825

This Article is brought to you for free and open access by the U.S. Department of Agriculture: Agricultural Research Service, Lincoln, Nebraska at DigitalCommons@University of Nebraska - Lincoln. It has been accepted for inclusion in Publications from USDA-ARS / UNL Faculty by an authorized administrator of DigitalCommons@University of Nebraska - Lincoln. 


\title{
A crop water stress index and time threshold for automatic irrigation scheduling of grain sorghum
}

\author{
Susan A. O’Shaughnessy*, Steven R. Evett, Paul D. Colaizzi, Terry A. Howell \\ USDA-Agricultural Research Service, P.O. Drawer 10, 2300 Experiment Station Road, Bushland, TX 79012, USA
}

\section{A R T I C L E I N F O}

\section{Article history:}

Received 16 September 2011

Accepted 26 January 2012

Available online 24 February 2012

\section{Keywords:}

Automatic irrigation scheduling

CWSI Time Threshold

Grain sorghum

Plant feedback system

\begin{abstract}
A B S T R A C T
Variations of the crop water stress index (CWSI) have been used to characterize plant water stress and schedule irrigations. Usually, this thermal-based stress index has been calculated from measurements taken once daily or over a short period of time, near solar noon or after and in cloud free conditions. A method of integrating the CWSI over a day was developed to avoid the noise that may occur if weather prevents a clear CWSI signal near solar noon. This CWSI and time threshold (CWSI-TT) was the accumulated time that the CWSI was greater than a threshold value (0.45); and it was compared with a time threshold (CWSI-TT) based on a well-watered crop. We investigated the effectiveness of the CWSI-TT to automatically control irrigation of short and long season grain sorghum hybrids (Sorghum bicolor (L.) Moench, NC+ 5C35 and Pioneer 84G62); and to examine crop response to deficit irrigation treatments (i.e. $80 \%, 55 \%, 30 \%$ and $0 \%$ of full replenishment of soil water depletion to $1.5-\mathrm{m}$ depth). Results from automated irrigation scheduling were compared to those from manual irrigation based on weekly neutron probe readings. In 2009, results from the Automatic irrigation were mixed; biomass yields in the $55 \%$ and $0 \%$ treatments, dry grain yields in the $80 \%$ and $0 \%$ treatments, and WUE in the $80 \%, 55 \%$, and $0 \%$ treatments were not significantly different from those in the corresponding Manual treatments. However, dry grain yields in the 55\% and 30\% treatments were significantly less than those in the Manual control plots. These differences were due mainly to soil water variability in the beginning of the growing season. This conclusion is reinforced by the fact that IWUE for dry grain yield was not significantly different for $30 \%$ and 55\% treatments, and was significantly greater for Automatic control at $80 \%$. In 2010, there were no significant differences in biomass, dry grain yield, WUE, or IWUE for irrigation control methods when compared across the same amount treatments. Similar results between irrigation methods for at least the highest irrigation rate ( $80 \%$ of soil water depletion) in 2009 and among all irrigation treatment amounts in 2010 indicate that the CWSI-TT method can be an effective trigger for automatically scheduling either full or deficit irrigations for grain sorghum in a semi-arid region.
\end{abstract}

Published by Elsevier B.V.

\section{Introduction}

Sorghum is important to the livestock and ethanol industries in the United States. Both early and late maturing varieties of grain sorghum are grown in the Northern High Plains area of Texas, where approximately $40 \%$ of grain sorghum is irrigated, resulting in yields double those from dryland farming (Colaizzi et al., 2009). Irrigation in this semi-arid region is accomplished primarily with center pivot systems. If irrigation strategies can be automated, farmers can save time and labor by allowing the automated system to monitor crop water status and help determine when to apply irrigations. If automated irrigation systems produce yields and water use efficiencies comparable to those resulting from prior best irrigation scheduling practices, then farmers can realize greater profitability.

\footnotetext{
* Corresponding author. Tel.: +1 806356 5770; fax: +1 8063565750.

E-mail address: Susan.OShaughnessy@ars.usda.gov (S.A. O'Shaughnessy).
}

The theoretical crop water stress index (CWSI) developed by Jackson et al. (1981) was based on energy balance analysis. This thermal stress index has been investigated to characterize plant water stress (Howell et al., 1986; Yuan et al., 2004; Möeller et al., 2007), estimate crop productivity and water stress relationships (Wanjura et al., 1990), and has been used as a tool for irrigation timing (Throssel et al., 1987; Nielsen, 1990; Garrot et al., 1994; Gontia and Tiwari, 2008), usually in its empirical form. The theoretical CWSI incorporates incoming solar radiation, relative humidity, air temperature, wind speed, canopy resistance at potential evapotranspiration, and crop height. Its general form is:

$$
\text { CWSI }=\frac{\left(T_{\mathrm{c}}-T_{\mathrm{a}}\right)-\left(T_{\mathrm{c}}-T_{\mathrm{a}}\right)_{\mathrm{ll}}}{\left(T_{\mathrm{c}}-T_{\mathrm{a}}\right)_{\mathrm{ul}}-\left(T_{\mathrm{c}}-T_{\mathrm{a}}\right)_{\mathrm{ll}}}
$$

where $\left(T_{\mathrm{c}}-T_{\mathrm{a}}\right)$ is the measured difference between crop canopy temperature and air temperature, $\left(T_{\mathrm{c}}-T_{\mathrm{a}}\right)_{\mathrm{ll}}$ is the lower limit representing the temperature difference for a well watered crop, and $\left(T_{\mathrm{c}}-T_{\mathrm{a}}\right)_{\mathrm{ul}}$ is the upper limit representing the temperature 
Table 1

Summary of agronomics for 2009 and 2010 growing seasons in Bushland, Texas.

\begin{tabular}{|c|c|c|}
\hline $\begin{array}{l}\text { Growing season } \\
\text { Crop variety }\end{array}$ & $\begin{array}{l}2009 \\
\mathrm{NC}+5 \mathrm{C} 35\end{array}$ & $\begin{array}{l}2010 \\
\text { Pioneer 84G62 }\end{array}$ \\
\hline Fertilizer & $\begin{array}{l}\text { Fertigated w/N } 56 \mathrm{~kg} \mathrm{ha}^{-1} \text { (DOY 191) Fertigated w/N } \\
28 \mathrm{~kg} \mathrm{ha}^{-1} \text { (DOY 196) }\end{array}$ & Fertigated w/215 kg ha-1 (DOY 125) \\
\hline Planting date & June 24 (DOY 175) & June 1 (DOY 152) \\
\hline Planting rate & 200,000 seeds ha ${ }^{-1}$ & 205,000 seeds ha ${ }^{-1}$ \\
\hline Initial neutron access tube reading & Jul 6 (DOY 187) & Jun 15 (DOY 166) \\
\hline Automatic irrigation scheduling dates & Jul 23 (DOY 204) to Sep 29 (DOY 272) & Jul 5 (DOY 186) to Sep 10 (DOY 253) \\
\hline Plant mapping dates & $\begin{array}{l}\text { Jul } 20 \text { (DOY 201), Jul } 30 \text { (DOY 211), Aug } 11 \text { (DOY 223), Sep } \\
4 \text { (DOY 247), Sep } 27 \text { (DOY 270) }\end{array}$ & $\begin{array}{l}\text { Jul } 21 \text { (DOY 202), Aug } 3 \text { (DOY 215), Aug } 12 \text { (DOY 224), Sep } \\
8 \text { (DOY 251), Sep } 22 \text { (DOY 265), Oct 15(DOY 288) }\end{array}$ \\
\hline Herbicide application & $\begin{array}{l}\text { G-Max Lite (dimethenamid-P, dimethyl-thien-3, atrazine), } \\
\text { 3.2 } \text { L ha }^{-1} \text {, May } 28 \text { (DOY 148) }\end{array}$ & $\begin{array}{l}\text { Bicep II Lite (Atrazine, S-metolachlor, 3.2 } \mathrm{L} \mathrm{ha}^{-1} \text { ), Jun } 29 \\
\text { (DOY 180) }\end{array}$ \\
\hline Hand sample harvest dates & Oct $23-30$ (DOY $296-303)$ & Oct $15-24$ (DOY 288-295) \\
\hline
\end{tabular}

difference between the crop canopy and ambient air when the plants are severely stressed (Jackson et al., 1988). The CWSI tends towards 0 after irrigations and progressively climbs towards 1 as soil water is depleted. Many studies have used differential irrigation amounts on different crops and calculated the corresponding CWSI values (alfalfa - Hattendorf et al., 1988; sorghum - Olufayo et al., 1996; Bermuda grass - Farahani et al., 1993; Emekli et al., 2007; corn - Yazar et al., 1999; cotton - Barbosa da Silva and Rao, 2005). A few studies have used an established CWSI value to trigger irrigations on soybean (Nielsen, 1990) and wheat (Garrot et al., 1994). Typically, the measurements were either instantaneous (Hattendorf et al., 1988; Nielsen, 1990; Farahani et al., 1993) or were taken as average values over a short interval usually near solar noon (Garrot et al., 1994; Olufayo et al., 1996; Ajayi and Olufayo, 2004; Gontia and Tiwari, 2008). Irrigation scheduling using the CWSI has not always been successful, and it has not become widely adopted. One problem is that instantaneous measurements, or mean values from measurements take over a short time period near solar noon, may be influenced by passing clouds, wind gusts or other micrometeorological incidents.

We hypothesized that assessing the CWSI over daylight hours would provide a more stable and relevant index for irrigation scheduling (i.e. timing) because it would average and thus smooth out the effects of short-term microclimatological events and more reliably respond to the plant water status. A method of integrating the CWSI over a day was developed. This CWSI-TT was the accumulated time that the stress index, CWSI, was greater than a threshold value (0.45), for a specified time threshold (CWSI-TT) based on a well-watered crop.

In this study, we compared a scientifically based manual method for irrigation scheduling that of direct soil water measurements using a neutron probe, to the automated plant-feedback method comprised of infrared thermometers (IRTs) and microclimatological instrumentation for remote sensing of crop water status. While farmers or crop advisers can use a neutron probe to determine soil water status, the disadvantages of the neutron scattering method include the radiation hazard and attendant licensing requirements, relatively poor (and uncertain) spatial resolution, and the soil specific calibration requirement (Or and Wraith, 2002). The initial investment for a neutron probe ranges in cost from $\$ 4000$ to $\$ 6000$. The system for remotely sensing crop water status with IRTs and meteorological instrumentation is variable depending on the number of IRTs and the manufacturer. However, with the advent of low-cost wireless sensors (Mahan et al., 2010; O'Shaughnessy et al., 2011) and sensor network systems (O'Shaughnessy and Evett, 2010), the cost is closer to the lower-end of the purchase price for a single neutron probe. Additionally automated systems using the center pivot as a platform for IRTs can be used to provide crop canopy temperature maps on a frequent basis (Peters and Evett, 2007), which will have better spatial and temporal resolution than weekly neutron probe readings.
The objectives of this study were to: (1) investigate the effectiveness of the CWSI-TT method to automatically trigger irrigations; and (2) and to examine grain sorghum response to deficit irrigation treatment amounts in a semi-arid region.

\section{Materials and methods}

\subsection{Experimental site}

Experiments took place at the Conservation Production and Research Laboratory, Bushland, TX $\left(35^{\circ} 11^{\prime} \mathrm{N}, 102^{\circ} 06^{\prime} \mathrm{W}, 1174 \mathrm{~m}\right.$ above mean sea level). The field soil was a Pullman clay loam, a fine, mixed, superactive, thermic, Torrertic Paleustoll (Soil Survey Staff, 2004). The field capacity $\left(0.33 \mathrm{~m}^{3} \mathrm{~m}^{-3}\right)$ and wilting point $\left(0.18 \mathrm{~m}^{3} \mathrm{~m}^{-3}\right)$ water contents were assumed uniform across the center pivot field. The climate is semi-arid with an average annual rainfall of $470 \mathrm{~mm}$.

\subsection{Sorghum varieties and agronomics}

We used a short and long season variety in this experiment since both varieties are important to farmers in this area. Almost invariably, a full-season variety will out-yield a good early-season hybrid, other conditions being equal and favorable for sorghum growth. But, short season varieties use less water over a growing season and can be used as a replacement crop or may provide economic relief if an earlier crop is damaged due to extreme weather conditions or harmful chemical residuals. Early maturing or short season (SS) grain sorghum (Sorghum bicolor (L.) Moench), variety NC+ 5C $35,{ }^{1}$ was planted on day of year (DOY) 175 (June 24) in 2009, and a late maturing variety or long season (LS) sorghum, Pioneer 84G62, was planted on June 1 (DOY 152) in 2010. Both crops were planted in concentric rows on beds spaced 0.76- $\mathrm{m}$ apart under a three span center pivot irrigation system. Irrigations were applied using low energy precision application (LEPA) drag socks (Lyle and Bordovsky, 1983 ) in every other furrow. Dikes were placed in the furrows to reduce runoff. The sorghum varieties were cultivated in a manner similar to production practices in the region. Fertilizer was applied based on preplant soil samples tested by a commercial soil testing laboratory. The low nitrogen application for 2009 indicates residual nitrogen from the previous year's fallowed field after a failed cotton crop. Fertilizers and herbicides for weed control were applied through the pivot lateral (Table 1 ).

Total above-ground biomass and grain yields were handharvested from a $10 \mathrm{~m}^{2}$ area in each of the 48 treatment plots prior

\footnotetext{
1 The mention of trade names of commercial products in this article is solely for the purpose of providing specific information and does not imply recommendation or endorsement by the U.S. Department of Agriculture. USDA is an Equal Opportunity Employer.
} 


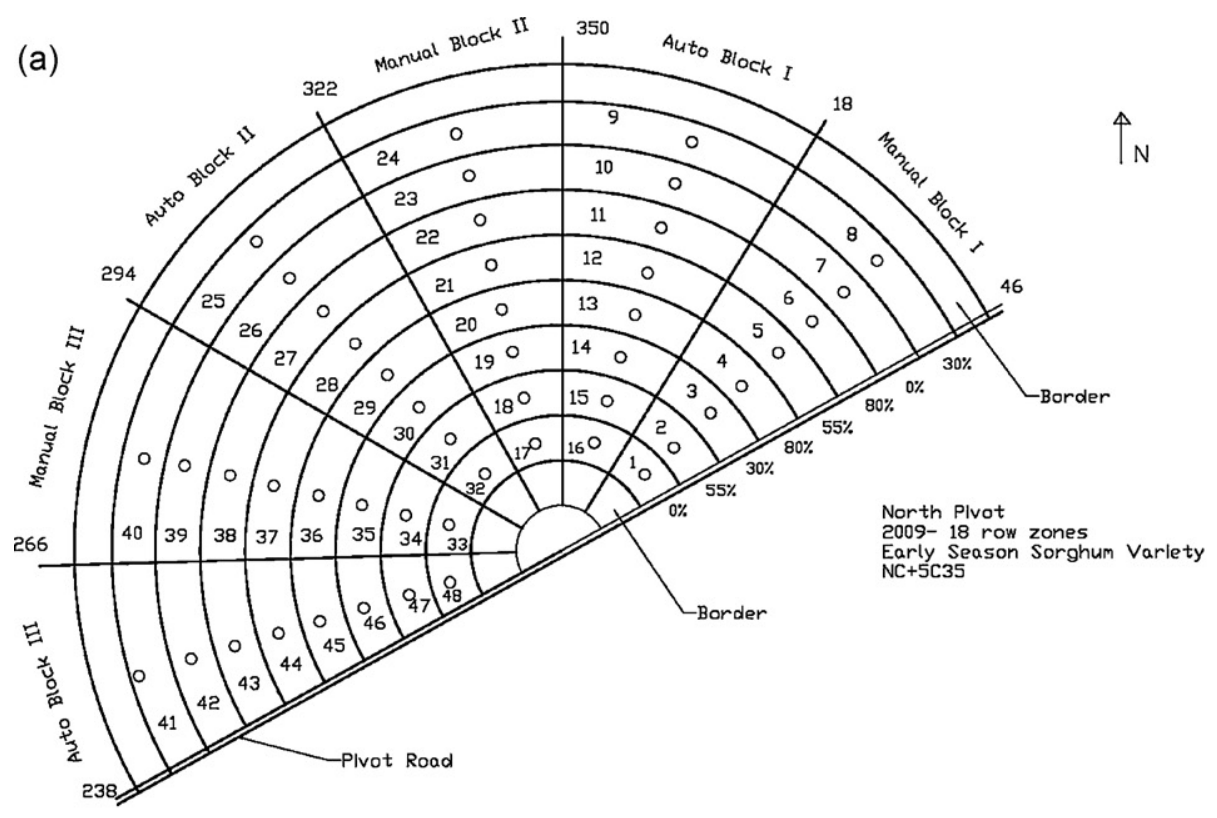

(b)

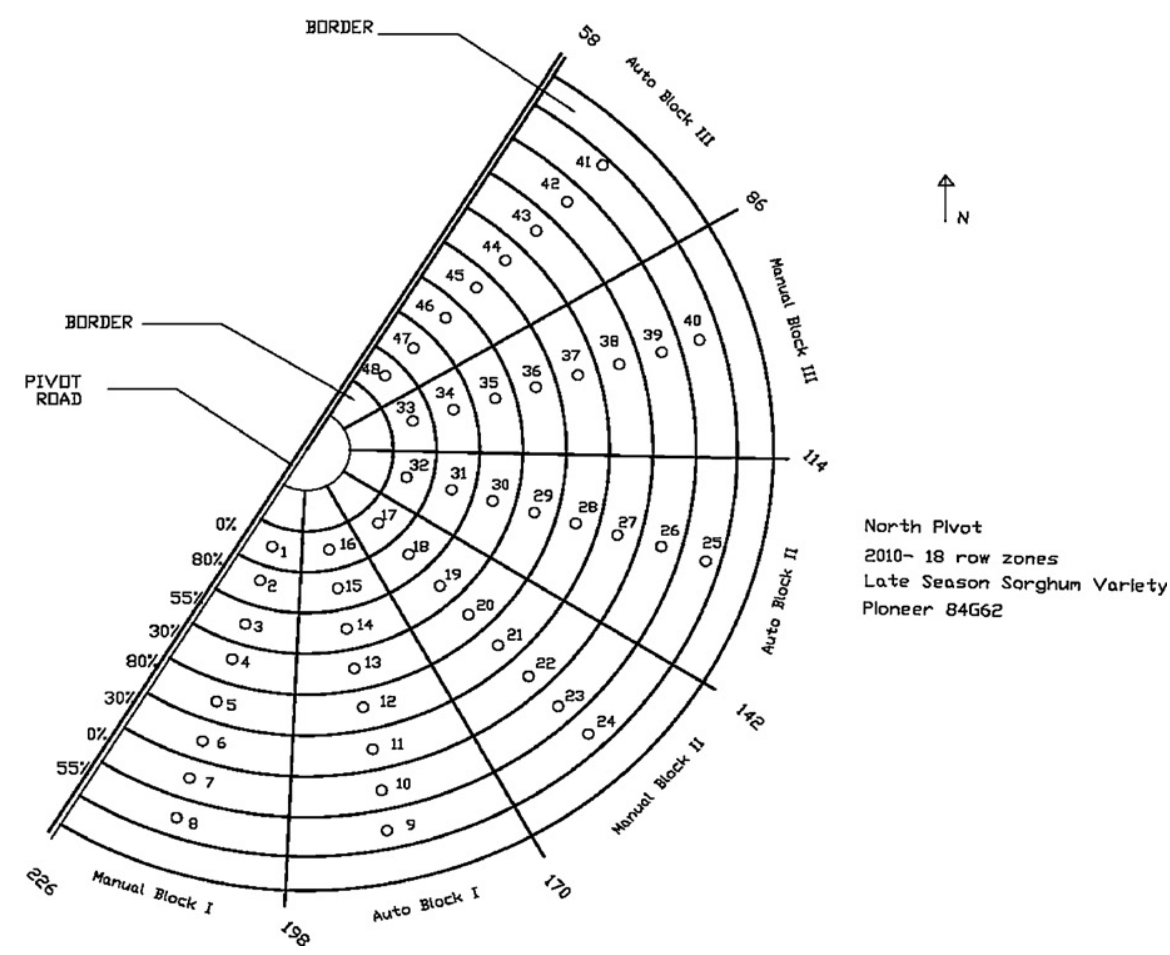

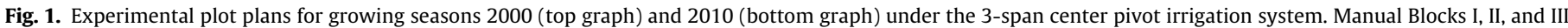
were irrigated based on weekly neutron probe readings and Automatic Blocks I, II, and III were irrigated automatically based on the CWSI-TT trigger.

to mechanical harvesting. Biomass samples were dried in an oven at $60^{\circ} \mathrm{C}$, and heads were stored in cotton bags and air-dried at room temperature in a drying room.

\subsection{Treatments and plot design}

Two irrigation control method treatments were used; Automatic and Manual as described later. For each irrigation control method, four irrigation amount treatments were applied ( $80 \%, 55 \%$, $30 \%$, and $0 \%$ (dryland) of full; full being defined differently for automatic and manual control methods as discussed later). Treatment plots were arranged in six blocks arc-wise around half of the center pivot circle (Fig. 1a and b) with alternating blocks for manual and automatic irrigation scheduling. Within each block, irrigation treatment amounts were randomly assigned with two replications arranged radially from the pivot point. Radial and arc-wise blocking was designed to control for effects of position along the lateral on irrigation application rate and to control for effects of possible runoff. Typically, alternating halves of our pivot fields are cropped each year for experimentation and a cover crop is grown on the opposite semi-circle to help even-out the soil water profile. In 2009, however, it was necessary to plant sorghum on the same semi-circle where cotton was grown under differential irrigation treatments in the previous year. 


\subsection{Manual irrigation scheduling}

Manual irrigations were scheduled over 2-3 days in a 7-day period, following weekly soil water readings by neutron methods usually taken on Monday mornings. Manual irrigations were performed on odd-numbered days of the year (DOY) based on $80 \%$, $55 \%, 30 \%$, and $0 \%$ (designated $\mathrm{I}_{80 \% \mathrm{M}}, \mathrm{I}_{55 \% \mathrm{M}}, \mathrm{I}_{30 \% \mathrm{M}}$, and $\mathrm{I}_{0 \% \mathrm{M}}$, respectively) of full replenishment to field capacity of water depletion in the top $1.5 \mathrm{~m}$ of soil. Soil water content was determined using a neutron probe (NP) (model 503DR, Campbell Pacific Nuclear, Martinez, CA) in $0.2-\mathrm{m}$ increments down to $2.4 \mathrm{~m}$ in the $\mathrm{I}_{80 \% \mathrm{M}}$ treatment plots. In all other treatment plots, soil water was measured once every 30 days for soil water balance computation of evapotranspiration (ET) only. Access tubes were placed in a row in the center of each plot (18 rows wide). The neutron probe was field calibrated to accuracy of better than $0.01 \mathrm{~m}^{3} \mathrm{~m}^{-3}$, resulting in separate calibrations from three distinct soil layers, Ap, Bt and Btca, using methods described by Evett (2008). Any rainfall occurring prior to irrigation of the total amount for the week was subtracted from the required total. Irrigation level was determined by nozzle discharge rate, horizontal spacing of the drop hoses, and the travel speed of the center pivot.

\subsection{Automatic irrigation scheduling}

When scheduled by the CWSI-TT algorithm, automatic irrigations were applied on even DOY. The CWSI-TT algorithm used a CWSI threshold of 0.45 , and a time threshold of $420 \mathrm{~min}$. These thresholds were determined from well-watered grain sorghum grown on weighing lysimeter fields at Bushland, Texas in 1988. The CWSI was calculated every $5 \mathrm{~min}$, and each time the index was greater than 0.45 during daylight hours, 5 min of time were accumulated. At midnight, if the cumulative time for the past $24 \mathrm{~h}$ was greater than $420 \mathrm{~min}$, then an irrigation was scheduled to be applied using computer control over the automatic blocks of the field the following morning. Because Manual and Automatic irrigations were scheduled on alternate days, the full irrigation level for automatic treatments was based on twice the peak daily crop water use rate of grain sorghum at the location $(2 \times 10 \mathrm{~mm}=20 \mathrm{~mm})$ (Steiner et al., 1991). Irrigations for the automatic control treatments were $80 \%, 55 \%, 30 \%$ and $0 \%$ (designated $\mathrm{I}_{80 \% \mathrm{~A}}, \mathrm{I}_{55 \% \mathrm{~A}}, \mathrm{I}_{30 \% \mathrm{~A}}$, and $\mathrm{I}_{0 \% \mathrm{~A}}$ ) of $20 \mathrm{~mm}$. Automatic irrigation scheduling was initiated when the SS variety was in the 5th leaf stage, summer 2009, and when the LS variety was in the 7th leaf stage during the summer of 2010.

\subsection{Canopy temperature and microclimate instrumentation}

A total of 16 infrared thermometers (IRTs) (Exergen model IRt/c.5:1-Type T, Watertown, Mass.) were mounted on the pivot lateral and wired to a datalogger (CR21X, Campbell Scientific, Logan, UT) to measure and record crop canopy temperature $\left(T_{\mathrm{c}}\right)$. The IRT sensors were calibrated in a controlled temperature environment using a blackbody calibrator (CES100, Electro Optical Industries, Inc., Santa Barbara, CA). Sensors were mounted on vertical masts placed at opposite edges of each concentric treatment plot, with two sensors facing inwards towards the canopy in each plot at an oblique, down-looking angle to reduce sun angle effects and viewing of bare soil. The sensors were located forward of the drop hoses approximately $1.5 \mathrm{~m}$ above the crop canopy. An IRT was placed in each of the two $\mathrm{I}_{80 \% \mathrm{~A}}$ treatment plots in Auto Block I (Fig. 1) to record reference temperature for a well-watered crop. Crop canopy temperatures recorded from the moving irrigation system were averaged for the period of time it took for the system to move across each plot, and so represented a mean one-time-of-day plot-specific temperature. These plot-specific temperatures were scaled using the method of Peters and Evett (2004) to produce estimates of the plot temperature over the entire daytime. Wind speed $\left(u_{z}\right)$ and solar radiation $\left(R_{\mathrm{s}}, \mathrm{W} \mathrm{m}^{-2}\right)$ were measured every $2 \mathrm{~s}$ at a height $(z)$ of $2 \mathrm{~m}$ (using a RM-Young Wind Sentry Set and LI-COR 200SZ, respectively) using a datalogger (model CR10X, Campbell Scientific, Logan, UT) located in plot 12 (Fig. 1) and reported as 5-min mean values. Air temperature $\left(T_{\mathrm{a}},{ }^{\circ} \mathrm{C}\right)$, relative humidity $(\mathrm{RH}, \%)$, and precipitation $(P, \mathrm{~mm})$ were measured using a HMPC45 probe and TE- $52 \mathrm{~mm}$ bucket wired to a datalogger (CR10X, Campbell Scientific, Logan, UT) mounted near the end of the pivot lateral. Data from each of the dataloggers were transmitted using radio frequency (RF) telemetry in the $900 \mathrm{MHz}$ frequency to a base station computer located at the pivot point.

\subsection{CWSI calculations}

The upper $\left(T_{\mathrm{ul}}\right)$ and lower temperatures $\left(T_{\mathrm{ll}}\right)$, boundaries of the CWSI, were calculated from measured environmental parameters paired with scaled canopy temperature data using equations from FAO-56 (Allen et al., 1998). The upper limit was calculated for a
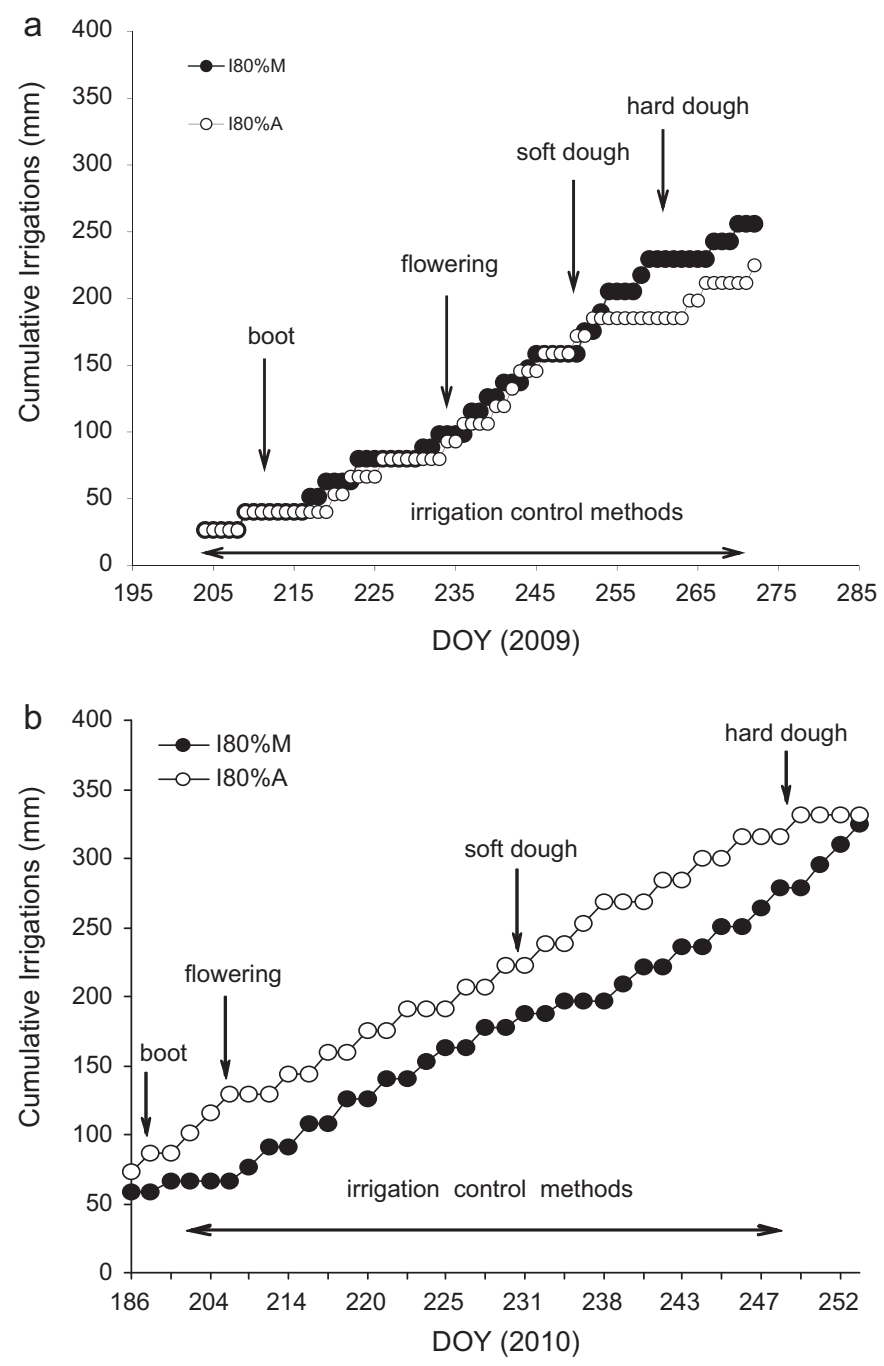

Fig. 2. (a) Cumulative irrigations for the manual and automatic irrigation control methods plotted with time and key growth stages for 2009.Irrigations for the automatic treatments kept up with those for the manual control plots until DOY 251; (b) in 2010, automatic irrigation scheduling started on DOY 186. During the last week of the irrigation season, Sep 3 to Sep 10 (DOY 247-252), no automatic irrigation signals were received. 
Table 2

Climatic conditions for 2009 and 2010 growing seasons.

\begin{tabular}{|c|c|c|c|c|c|c|c|}
\hline Month & Min temp $\left({ }^{\circ} \mathrm{C}\right)$ & Max temp $\left({ }^{\circ} \mathrm{C}\right)$ & Min RH (\%) & Max RH (\%) & $\begin{array}{l}\text { Total monthly } \\
\text { precipitation (mm) }\end{array}$ & $\begin{array}{l}\text { Maximum daily solar } \\
\text { irradiance }\left(\mathrm{MJ} \mathrm{m}^{-2} \mathrm{~d}^{-1}\right)\end{array}$ & $\begin{array}{l}\text { Average daily } \\
\mathrm{ET}_{\mathrm{o}}{ }^{\mathrm{a}}\left(\mathrm{mm} \mathrm{d}^{-1}\right)\end{array}$ \\
\hline \multicolumn{8}{|c|}{ Growing season 2009} \\
\hline June & 16.8 & 31.3 & 23.1 & 87.6 & 61.1 & 24.4 & 7.1 \\
\hline July & 16.8 & 32.2 & 28.1 & 85.9 & 68.2 & 26.0 & 7.3 \\
\hline Aug & 16.2 & 31.4 & 27.8 & 85.2 & 48.3 & 24.9 & 6.7 \\
\hline Sept & 10.9 & 26.5 & 30.2 & 88.2 & 10.8 & 19.5 & 4.9 \\
\hline Oct & 4.0 & 18.8 & 37.8 & 88.8 & 39.4 & 11.9 & 3.3 \\
\hline \multicolumn{8}{|c|}{ Growing season 2010} \\
\hline June & 18.2 & 33.7 & 9.0 & 99.0 & 35.8 & 30.6 & 8.3 \\
\hline July & 18.3 & 31.0 & 44.6 & 94.2 & 10.0 & 27.9 & 7.0 \\
\hline Aug & 17.6 & 32.7 & 29.7 & 87.8 & 47.0 & 28.0 & 7.0 \\
\hline Sept & 14.8 & 30.9 & 27.4 & 89.0 & 13.2 & 27.9 & 5.9 \\
\hline Oct & 8.5 & 24.4 & 30.0 & 81.3 & 10.7 & 19.8 & 4.5 \\
\hline
\end{tabular}

a Reference evapotranspiration (ET $\mathrm{ET}_{0}$ ) data for grass from the Texas High Plains Evapotranspiration (TXHPET) Network.

non-transpiring crop (latent heat of evaporation=0) using the equation (Jackson et al., 1988):

$\left(T_{\mathrm{c}}-T_{\mathrm{a}}\right)_{\mathrm{ul}}=\frac{r_{\mathrm{a}}\left(R_{\mathrm{n}}-G\right)}{\rho C_{\mathrm{p}}}$

where $R_{\mathrm{n}}$ is the net radiation ( $\mathrm{MJ} \mathrm{m} \mathrm{m}^{-2} \mathrm{~d}^{-1}$ ) is estimated as the difference between incoming net shortwave and outgoing net longwave radiation using Eqs. (38), (39), and (40) in FAO-56 and an albedo $(\alpha)=0.23 ; G=$ soil heat flux $\left(\mathrm{MJ} \mathrm{m}^{-2} \mathrm{~d}^{-1}\right)$ is estimated using Eq. (45) from FAO-56; $\rho\left(\mathrm{kg} \mathrm{m}^{-3}\right)$ is the density of air approximated as a function of air temperature; $C_{p}=$ specific heat capacity of dry air (1013 $\mathrm{J} \mathrm{kg}^{-1}{ }^{\circ} \mathrm{C}^{-1}$ ); and $r_{\mathrm{a}}$ is aerodynamic resistance (Eq. (4)). Using this upper boundary equation, assumes bulk canopy resistance, $r_{\mathrm{c}}$, approaches infinity. The lower limit, representing a fully transpiring crop, $\left(T_{\mathrm{c}}-T_{\mathrm{a}}\right)_{\mathrm{ll}}$ is calculated using:

$\left(T_{\mathrm{c}}-T_{\mathrm{a}}\right)_{\mathrm{ll}}=\left(\frac{r_{\mathrm{a}} R_{\mathrm{n}}}{\rho C_{\mathrm{p}}}\right)\left(\frac{\gamma}{\Delta+\gamma}\right)-\frac{e_{\mathrm{s}}-e_{\mathrm{a}}}{\Delta+\gamma}$

where $\gamma$ is the psychometric constant $\left(\mathrm{P}_{\mathrm{a}}{ }^{\circ} \mathrm{C}^{-1}\right) ; \Delta$ is the slope of the saturated vapor pressure-temperature relationship calculated at the average of canopy and air temperature expressed in ${ }^{\circ} \mathrm{C}$ (as in Jackson et al., 1988); $e_{\mathrm{s}}$ is saturated vapor pressure, $\mathrm{e}_{\mathrm{a}}$ is actual vapor pressure, and $r_{\mathrm{a}}$ is aerodynamic resistance $\left(\mathrm{s} \mathrm{m}^{-1}\right)$, computed as Eq. (4) (FAO-56):

$r_{\mathrm{a}}=\frac{\left(\ln \left(z_{\mathrm{m}}-d\right) / z_{\mathrm{om}}\right)\left(\ln (z h-d) / z_{\mathrm{oh}}\right)}{k^{2} u_{\mathrm{z}}}$

where $z_{\mathrm{m}}$ is the height of wind measurements $(\mathrm{m}) ; z_{\mathrm{om}}$ the roughness length $(\mathrm{m})$ for momemtum transfer, approximated by $0.123 \times$ crop height; $z_{\mathrm{h}}$ the height of humidity measurements $(\mathrm{m}) ; d$ the zero plane displacement height $(\mathrm{m})$, approximated by $2 / 3 \times$ crop height; $z_{\text {oh }}$ the roughness length governing transfer of heat and vapor $(\mathrm{m})$, approximated by $0.1 \times z_{\mathrm{om}} ; k=$ von Karman's constant $=0.41$; and $u_{\mathrm{z}}=$ wind speed $\left(\mathrm{m} \mathrm{s}^{-1}\right)$. Crop height was estimated using data from sorghum grown on the large weighing lysimeter fields at Bushland, TX.

\subsection{Water use and water use efficiency calculations}

Crop water use $\left(\mathrm{ET}_{\mathrm{c}}, \mathrm{mm}\right)$ was calculated using the soil water balance equation (Evett, 2002):

$\mathrm{ET}_{\mathrm{C}}=P+I+F-\Delta S-R$

where $\mathrm{ET}_{\mathrm{c}}$ is evapotranspiration, $\Delta S$ is the change in soil water stored in the profile as determined using the NP (final minus initial soil water reading), $R$ is runoff, $P$ is precipitation $(\mathrm{mm}), I$ is the irrigation water applied ( $\mathrm{mm}$ ), and $F$ is flux across the lower boundary of the control volume (taken as positive when entering the control volume), all in units of mm. Runoff and flux were assumed to be negligible because the field was furrow diked, plots were large enough that horizontal fluxes were important only in plot borders, and NP measurements indicated negligible flux in the 2.1 to $2.3-\mathrm{m}$ depth range.

The average daily fractional soil water depletion $\left(D_{\mathrm{f}}\right)$ in the root zone of the $\mathrm{I}_{80 \% \mathrm{~A}}$ treatment plots was calculated as $D_{\mathrm{f}}=D_{\mathrm{p}} / \mathrm{TAW}$ where $D_{\mathrm{p}}$ (depletion) was calculated using a daily soil water balance (Chapter 8-FAO-56 in Allen et al., 1998). Total available water (TAW) is the total of the plant available water in the root zone (depth of $1.5 \mathrm{~m}$ ) at field capacity. Daily $D_{\mathrm{f}}$ was compared to daily average CWSI-TT values from the I $_{80 \%}$ treatment plots. The comparison was only made between values from these plots since the irrigation triggers were based on data from these plots.

Water use efficiency $\left(\mathrm{kg} \mathrm{m}^{-3}\right)$ was calculated as

$\mathrm{WUE}=\frac{Y_{\mathrm{g}}}{\mathrm{ET}_{\mathrm{C}}}$

where $Y_{\mathrm{g}}$ is the economic yield $\left(\mathrm{g} \mathrm{m}^{-2}\right)$, and $\mathrm{ET}_{\mathrm{c}}$ is the crop water use (Howell, 2002). Irrigation water use efficiency (IWUE, $\mathrm{kg} \mathrm{m}^{-3}$ ) was calculated as

$\operatorname{IWUE}=\frac{\left(Y_{\mathrm{gi}}-Y_{\mathrm{gd}}\right)}{\mathrm{IRR}_{i}}$

where $Y_{\mathrm{gi}}$ is the economic yield $\left(\mathrm{g} \mathrm{m}^{-2}\right)$ in the $i$ th treatment level, $Y_{\mathrm{gd}}$ is the dryland yield $\left(\mathrm{g} \mathrm{m}^{-2}\right)$, and $\mathrm{IRR}_{i}$ is the irrigation water applied (mm) (Howell, 2002).

\subsection{Statistical analysis}

Results from each year were analyzed using the General Linear Models (GLM) procedures, and the Bonferroni $t$-test to perform multiple comparisons of treatment means at $p=0.05$. Statistical software was SAS (SAS 9.2, SAS Institute Inc., Cary, NC).

\section{Results and discussion}

\subsection{Climate and precipitation}

In 2009, rainfall from June through October totaled $228 \mathrm{~mm}$, which was typical for the area and time of year. Seventy-four percent of rainfall for this growing season occurred between boot and flowering stage. In 2010, the majority of precipitation again fell between boot and flowering stage; however, the total precipitation for the 2010 growing season was $46 \%$ less than for 2009. Maximum daily temperatures and grass reference $\mathrm{ET}\left(\mathrm{ET}_{0}\right)$ values were also greater in August through October of 2010 than in 2009 (Table 2). 
Table 3

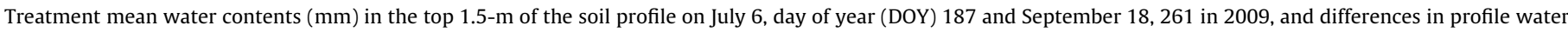
content between manual (Man) and automatic (Auto) methods at the same irrigation amount treatment.

\begin{tabular}{|c|c|c|c|c|c|c|}
\hline \multirow[t]{2}{*}{ Irrig. amount treatment } & \multicolumn{3}{|c|}{$\begin{array}{l}\text { July } 6 \text { (DOY } 187 \text { ) } \\
\text { Control method }\end{array}$} & \multicolumn{3}{|c|}{$\begin{array}{l}\text { September } 18 \text { (DOY 261) } \\
\text { Control method }\end{array}$} \\
\hline & Man & Auto & Difference (Man - Auto) & Man & Auto & Difference (Man - Auto) \\
\hline $\mathrm{I}_{0 \%}$ & 393.9 & 394.7 & -0.8 & 323.2 & 319.2 & 4 \\
\hline $\mathrm{I}_{30 \%}$ & 416.6 & 401.4 & 15.2 & 375.5 & 350.4 & 25.1 \\
\hline $\mathrm{I}_{55 \%}$ & 398.2 & 396.6 & 1.6 & 381.8 & 357.1 & 24.7 \\
\hline $\mathrm{I}_{80 \%}$ & 421.1 & 412.5 & 8.6 & 454.1 & 401.2 & 52.9 \\
\hline
\end{tabular}

Table 4

Irrigation amounts applied to treatment plots in the 2009 and 2010 growing seasons at Bushland, TX.

\begin{tabular}{|c|c|c|c|c|}
\hline \multirow{2}{*}{$\begin{array}{l}\text { Growing season } \\
\text { Crop variety } \\
\text { Irrigation treatment amount/method }\end{array}$} & \multicolumn{2}{|c|}{$\begin{array}{l}2009 \\
\text { NC+ 5C35 (short season, SS) }\end{array}$} & \multicolumn{2}{|c|}{$\begin{array}{l}2010 \\
\text { Pioneer 84G62 (long season, LS) }\end{array}$} \\
\hline & Manual (mm) & $\overline{\text { Automatic }(\mathrm{mm})}$ & Manual (mm) & Automatic (mm) \\
\hline $80 \%$ & 263 & 238 & 324 & 332 \\
\hline $55 \%$ & 182 & 164 & 241 & 246 \\
\hline $30 \%$ & 99 & 89 & 158 & 161 \\
\hline $0 \%^{\mathrm{a}}$ & 62 & 62 & 58 & 58 \\
\hline
\end{tabular}

a Irrigations applied post plant prior to automatic irrigation scheduling to produce a uniform stand.

a

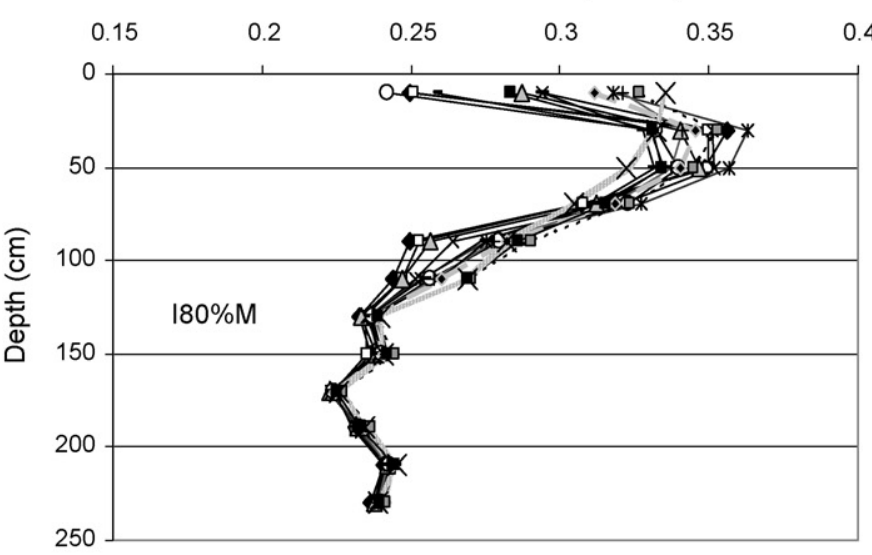

$\mathrm{b}$

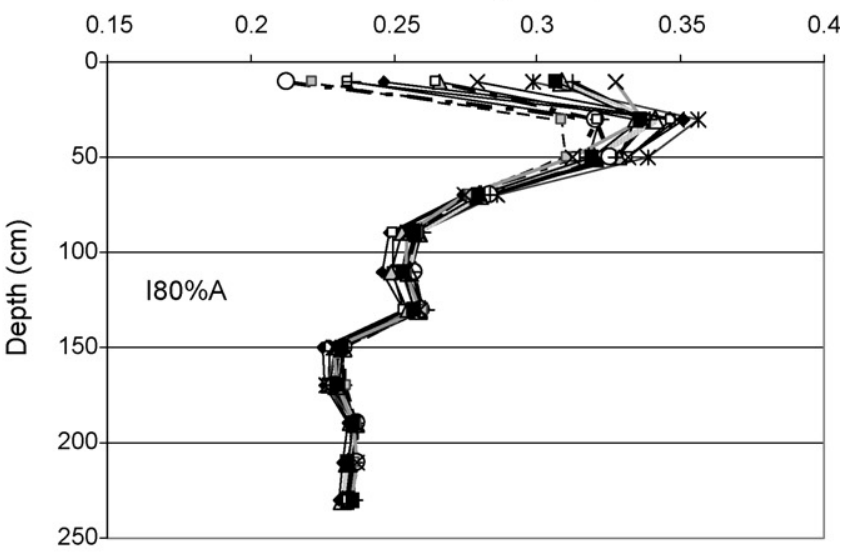

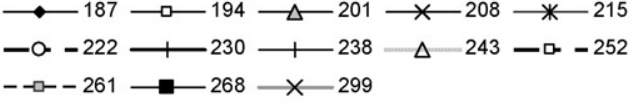

$\mathrm{d}$
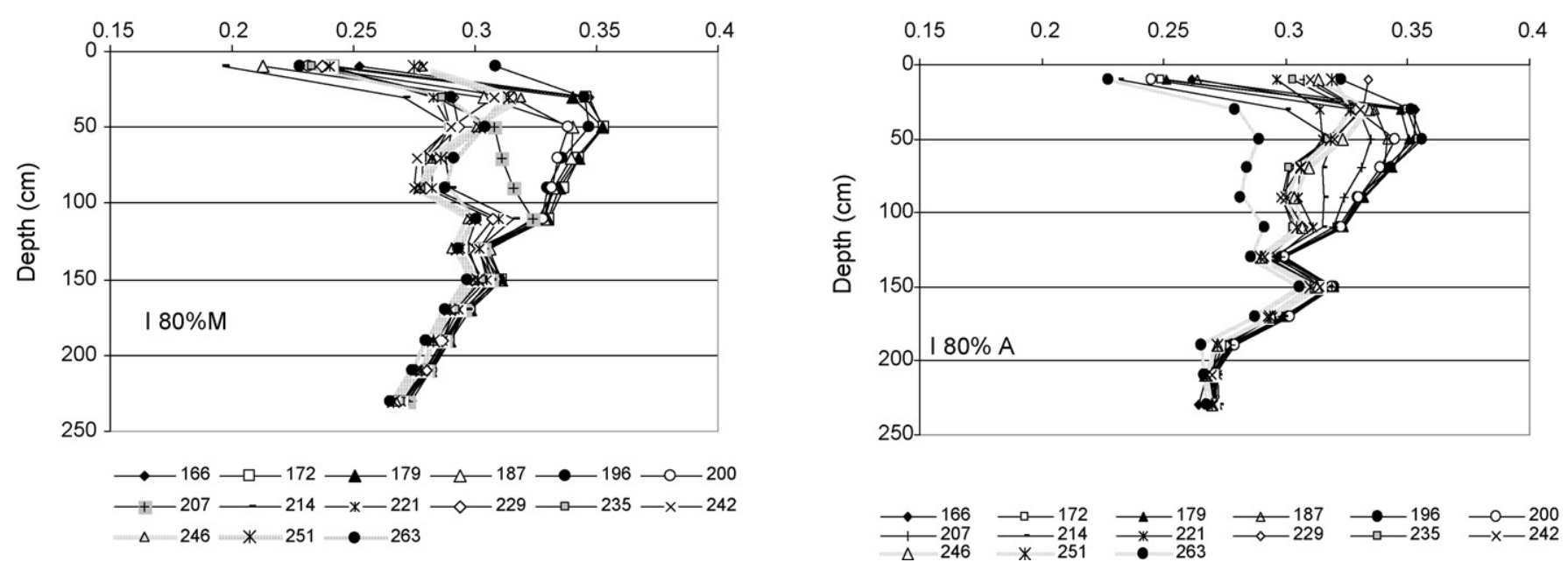

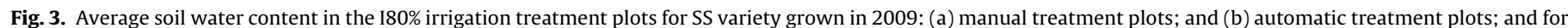
LS variety sorghum grown in 2010: [c] manual treatment plots; and (d) automatic treatment plots. 
Table 5

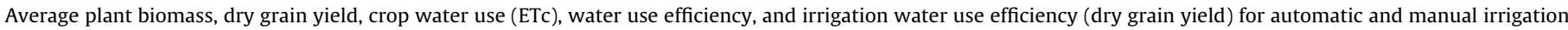

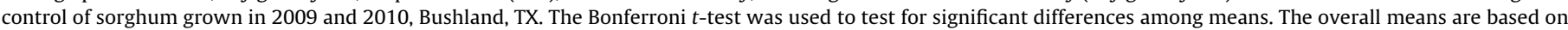

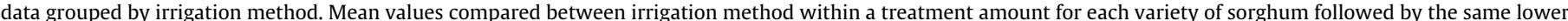

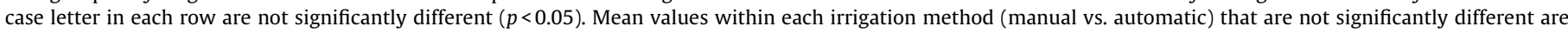

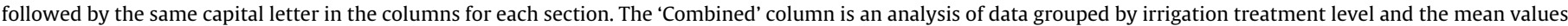
followed by the same capital letter are not significantly different.

\begin{tabular}{|c|c|c|c|c|c|c|}
\hline \multirow{2}{*}{$\begin{array}{l}\text { Growing season crop variety } \\
\text { Irrigation treatment amount/method }\end{array}$} & \multicolumn{3}{|c|}{2009 NC+ 5C35 (short season, SS) } & \multicolumn{3}{|c|}{2010 Pioneer 84G62 (long season, LS) } \\
\hline & Manual & Automatic & $\overline{\text { Combined }}$ & Manual & Automatic & Combined \\
\hline \multicolumn{7}{|l|}{ Biomass dry matter $\left(\mathrm{g} \mathrm{m}^{-2}\right)$} \\
\hline Overall mean & 1191a & $1113 a$ & NA & 1809a & $1817 a$ & NA \\
\hline $80 \%$ & 1648a,A & $1464 \mathrm{~b}, \mathrm{~A}$ & $1556 A$ & $2172 \mathrm{a}, \mathrm{A}$ & 2013a,A & $2092 \mathrm{~A}$ \\
\hline $55 \%$ & 1441a,B & 1369a,A & 1419B & $2062 a, A$ & $2095 a, A$ & $2075 A$ \\
\hline $30 \%$ & 1108a,C & 1031b,B & $1069 \mathrm{C}$ & 1755a,B & 1794a,B & $1775 \mathrm{~A}$ \\
\hline $0 \%$ & $568 \mathrm{a}, \mathrm{D}$ & $584 a, C$ & $576 \mathrm{D}$ & $1248 a, C$ & 1369a,C & $1306 \mathrm{~B}$ \\
\hline \multicolumn{7}{|l|}{ Dry grain yield $\left(\mathrm{kg} \mathrm{m}^{-2}\right)$} \\
\hline Overall mean & $0.58 \mathrm{a}$ & $0.56 b$ & NA & $0.68 \mathrm{a}$ & $0.74 a$ & NA \\
\hline $80 \%$ & $0.80 \mathrm{a}, \mathrm{A}$ & $0.81 \mathrm{a}, \mathrm{A}$ & $0.81 \mathrm{~A}$ & $0.88 \mathrm{a}, \mathrm{A}$ & $0.95 a, A$ & $0.91 \mathrm{~A}$ \\
\hline $55 \%$ & $0.77 \mathrm{a}, \mathrm{A}$ & $0.72 b, B$ & $0.74 \mathrm{~B}$ & $0.84 \mathrm{a}, \mathrm{A}$ & $0.82 \mathrm{a}, \mathrm{AB}$ & $0.86 \mathrm{~A}$ \\
\hline $30 \%$ & $0.54 a, B$ & $0.47 \mathrm{~b}, \mathrm{C}$ & $0.51 \mathrm{C}$ & $0.64 a, B$ & $0.75 a, B$ & $0.69 \mathrm{~B}$ \\
\hline $0 \%$ & $0.22 \mathrm{a}, \mathrm{C}$ & $0.22 \mathrm{a}, \mathrm{D}$ & $0.22 \mathrm{D}$ & $0.37 a, C$ & $0.44 a, C$ & $0.44 \mathrm{C}$ \\
\hline \multicolumn{7}{|l|}{$\mathrm{ET}_{\mathrm{c}}(\mathrm{mm})$} \\
\hline Overall mean & $358 a$ & $339 b$ & NA & $433 b$ & $454 a$ & NA \\
\hline $80 \%$ & 469a,A & $437 b, A$ & $453 \mathrm{~A}$ & 522a,A & 542a,A & $532 \mathrm{~A}$ \\
\hline $55 \%$ & 397a,B & 354b,B & $375 B$ & 466a,A & 505a,A & 493B \\
\hline $30 \%$ & $334 a, C$ & $329 a, C$ & $332 C$ & 411a,A & $427 a, A$ & $419 \mathrm{C}$ \\
\hline $0 \%$ & 233a,D & 235a,D & $234 \mathrm{D}$ & 334a,B & $345 a, B$ & $340 D$ \\
\hline \multicolumn{7}{|l|}{ Water use efficiency $\left(\mathrm{kg} \mathrm{m}^{-3}\right)$} \\
\hline Overall mean & $1.56 a$ & $1.57 \mathrm{a}$ & NA & $1.54 \mathrm{a}$ & $1.63 a$ & NA \\
\hline $80 \%$ & $1.72 \mathrm{a}, \mathrm{AB}$ & $1.86 \mathrm{a}, \mathrm{A}$ & 1.79B & $1.68 \mathrm{a}, \mathrm{A}$ & $1.75 \mathrm{a}, \mathrm{A}$ & $1.72 \mathrm{~A}$ \\
\hline $55 \%$ & $1.93 a, A$ & $2.04 \mathrm{a}, \mathrm{A}$ & $1.99 \mathrm{~A}$ & $1.80 \mathrm{a}, \mathrm{A}$ & $1.75 \mathrm{a}, \mathrm{A}$ & $1.77 \mathrm{~A}$ \\
\hline $30 \%$ & $1.61 \mathrm{a}, \mathrm{B}$ & $1.44 \mathrm{~b}, \mathrm{~B}$ & $1.52 \mathrm{C}$ & $1.56 a, A$ & $1.75 a, A$ & $1.65 \mathrm{~A}$ \\
\hline $0 \%$ & $0.96 a, C$ & $0.95 a, C$ & $0.95 \mathrm{D}$ & 1.12a,B & 1.26a,B & $1.19 \mathrm{~B}$ \\
\hline \multicolumn{7}{|c|}{ Irrigation water use efficiency - dry grain yield $\left(\mathrm{kg} \mathrm{m}^{-3}\right)$} \\
\hline Overall mean & $2.55 \mathrm{a}$ & $2.52 \mathrm{a}$ & NA & $2.38 \mathrm{a}$ & $2.45 a$ & NA \\
\hline $80 \%$ & $2.06 \mathrm{~b}, \mathrm{~B}$ & 2.32a,B & 2.19B & $1.90 \mathrm{a}, \mathrm{B}$ & 1.88a,B & 1.89B \\
\hline $55 \%$ & $2.78 \mathrm{a}, \mathrm{A}$ & $2.82 \mathrm{a}, \mathrm{A}$ & $2.80 \mathrm{~A}$ & $2.59 \mathrm{a}, \mathrm{A}$ & $2.40 \mathrm{a}, \mathrm{A}$ & $2.51 \mathrm{~A}, \mathrm{~B}$ \\
\hline $30 \%$ & $2.81 \mathrm{a}, \mathrm{A}$ & $2.41 \mathrm{a}, \mathrm{A}$ & $2.61 \mathrm{~A}$ & $2.64 \mathrm{a}, \mathrm{A}$ & $3.07 \mathrm{a}, \mathrm{A}$ & $2.86 \mathrm{~A}$ \\
\hline
\end{tabular}

NA, not applicable.

\subsection{Soil water and irrigations}

The soil water profile for the center pivot field at the beginning of the 2009 growing season was variable among treatment plots because circumstances forced cropping sorghum on the same field as had differential irrigation treatments for cotton in 2008. Those 2008 differential irrigation treatments resulted in soil water variability amongst the manual and automatic treatment plots at the beginning of the 2009 growing season (Table 3 ). Soil water variability in the $30 \%$ treatments was such that the mean initial water content was larger for the Manual treatments at the $50-230-\mathrm{cm}$ depths and remained so at depths $>50 \mathrm{~cm}$ throughout the season. For the 55\% treatments, mean initial water content was larger for the Manual treatment below the $70-\mathrm{cm}$ depth and continued so throughout the season. For the $80 \%$ treatments, mean initial water content was larger for the Manual treatment at the 50- and 70-cm depths, however, there was no clear difference in water contents between these Manual and the Automatic treatments at $90-\mathrm{cm}$ depth and below throughout the season.

Over the irrigation scheduling period (DOY 204-272), the Manual control treatments received $8-13 \%$ more water than those in the automatically irrigated blocks (Table 4). Cumulative automatic irrigations were comparable in volume to manual irrigations until DOY 255 (Sept 12) (Fig. 2). Small differences between air and canopy temperatures and higher levels of $\mathrm{RH}$ (minimum daily average of $40 \%$ and maximum daily average of $92 \%$ ) between DOY 255 and DOY 264 contributed to reduced CWSI levels, which reduced the number of automatic irrigations that were scheduled compared with those scheduled manually using soil water sensing.
In 2010, the soil water profile was nearly uniform among the 48 treatment plots; the average soil water content was $482 \mathrm{~mm}$ in the $1.5-\mathrm{m}$ profile $\left(0.32 \mathrm{~m}^{3} \mathrm{~m}^{-3}\right)$, which was near field capacity, with a standard deviation of $\pm 3 \mathrm{~mm}$. Uniformity of the soil water profile was improved by the precipitation received in the early months of the calendar year, and also by the fact that the field was fallowed in the previous year. Irrigation amount differences between the Automatic and Manual methods were less than 3\%; however, the automatic control method scheduled irrigations that did not match the Manual irrigations (i.e., NP readings did not indicate a need to irrigate manual control plots) early in the season. Cumulative irrigations in the $\mathrm{I}_{80 \% \mathrm{~A}}$ treatment plots were $39 \mathrm{~mm}$ greater than irrigations in the $\mathrm{I}_{80 \% \mathrm{M}}$ plots from July 5-July 31 (DOY 186-212). A frequent number of irrigation signals for the automatic control treatments were received during the week of Jul 19 to Jul 27,2010. A site visit to the field indicated that these signals were false positives due to the sensors on the pivot being aimed at acute angles from the vertical and looking mainly at soil rather crop canopy surfaces. This likely contributed to the IRTs viewing more soil background than canopy cover at the onset of the irrigation season. During August, the irrigation amounts were nearly equivalent between irrigation methods; and near the end of the irrigation season, Sep 8-10 (DOY 251 to DOY 253), three manual irrigations were not matched by the automatic control method (Fig. 2) due to cloud cover and ambient air temperatures exceeding canopy temperatures.

In addition to meeting crop water needs, irrigators are also concerned with the possibility of over-irrigating and causing surface runoff or deep percolation which can waste water and drive nutrients from the root zone. There was no evidence of deep percolation in any of the $80 \%$ irrigation treatment plots for years 2009 and 2010 

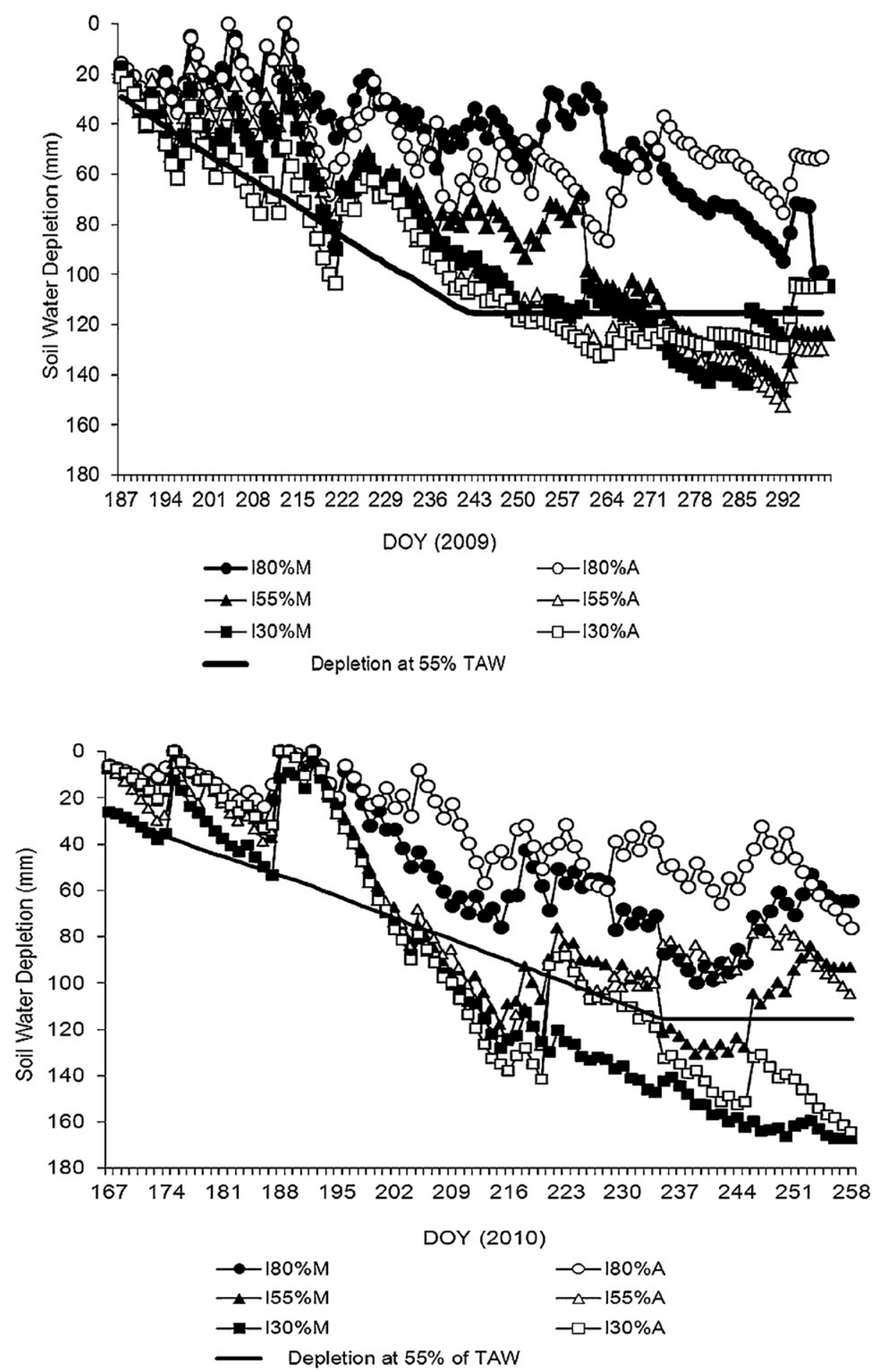

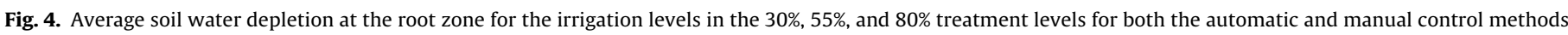
in years (top) 2009; and 2010 (bottom).

as soil water content at the lower depths were stable (Fig. 3). Manual irrigations were continued longer to reduce lodging, which was observed especially in the $30 \%$ treatment plots.

\subsection{Yield, $E T_{c}$, WUE, IWUE}

\subsubsection{Difference between irrigation control methods}

Data for each variety of sorghum were analyzed separately. Analyses were made across irrigation methods, grouped by irrigation treatment amounts to make comparisons between manual and automatic irrigation scheduling. In 2009, biomass dry matter was significantly greater for the $\mathrm{I}_{80 \mathrm{M} \%}(F$ statistic $=10.5, p=0.01)$, and $\mathrm{I}_{30 \mathrm{M} \%}$ treatment amounts $(F$ statistic $=5.46, p=0.04$ ) (Table 5$)$. There was no significant difference across irrigation scheduling methods between dry grain yields at the $\mathrm{I}_{80 \%}$ irrigation amount or at the $\mathrm{I}_{0 \%}$ amount. However, dry grain yields were significantly greater in the $\mathrm{I}_{55 \mathrm{M} \%}(F$ statistic $=5.15, p=0.05)$ and $\mathrm{I}_{30 \mathrm{M} \%}(F$ statistic $=6.17, p=0.03)$ control treatments. Crop water use $\left(\mathrm{ET}_{\mathrm{c}}\right)$ was significantly greater in $\mathrm{I}_{80 \mathrm{M} \%}(F=7.34, p=0.02)$ and in the $\mathrm{I}_{55 \mathrm{M} \%}(F=28.87, p=0.0003)$ treatments, and grain yields were higher. Water use efficiency in the 
a
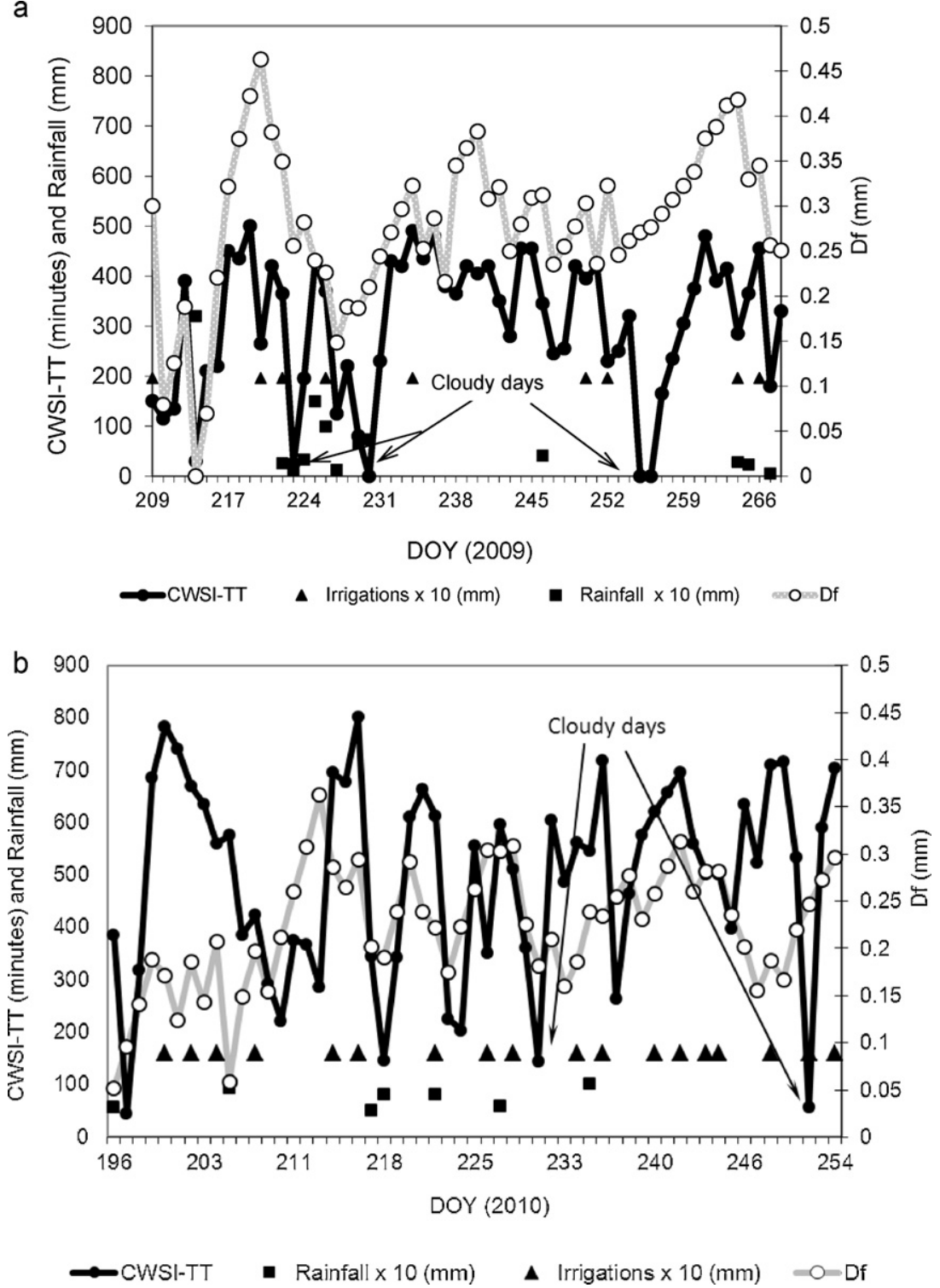

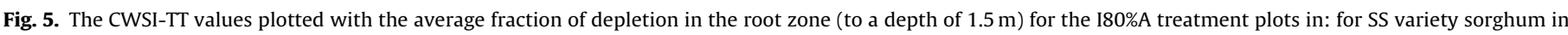
2009 (top diagram); and LS variety sorghum in 2010 (bottom diagram).

$\mathrm{I}_{30 \% \mathrm{~A}}(F=6.12, p=0.033)$ was significantly less than that for the $\mathrm{I}_{30 \% \mathrm{M}}$ treatment due to the low grain yield produced in the $\mathrm{I}_{30 \% \mathrm{~A}}$ treatment. Unger and Wiese (1979) reported an increase in sorghum yield of $17.6 \mathrm{~kg} \mathrm{ha}^{-1}$ for each $\mathrm{mm}\left(1.76 \mathrm{~kg} \mathrm{~m}^{-3}\right)$ increase in profile water content measured to $1.8-\mathrm{m}$ depth at planting. If applied to the differential in profile water content on DOY 187, this would give an estimated $268 \mathrm{~kg} \mathrm{ha}^{-1}$ yield increase for manual irrigation at the $30 \%$ level $\left(\mathrm{I}_{30 \% \mathrm{M}}\right)$, and a $27 \mathrm{~kg} \mathrm{ha}^{-1}$ yield increase for manual irrigation at the $55 \%$ level $\left(\mathrm{I}_{55 \% \mathrm{M}}\right)$, which would explain in part the smaller yields from the automatic treatments at the 30\% and 55\% irrigation levels ( $\mathrm{I}_{30 \% \mathrm{~A}}$ and $\mathrm{I}_{55 \% \mathrm{~A}}$, respectively) in 2009.

In 2010, there was no significant difference between the two irrigation-scheduling methods when comparing overall mean biomass and dry grain yield, WUE, and IWUE responses for the automatic and manual treatment plots (Table 5). Moreover, biomass and dry grain yield, $\mathrm{ET}_{\mathrm{c}}$, WUE and IWUE were not significantly different between irrigation methods within the same treatment amount. Given these results and the non-uniform initial conditions in 2009, we conclude that there was no important difference between the Manual and Automatic scheduling methods.

\subsubsection{Differences across irrigation amount treatments}

To investigate biomass, dry grain yield, WUE, and IWUE across different irrigation amount treatments, analyses were performed on data from all treatment plots for a given year (Table 5). In 2009 , biomass, dry grain yields, and $\mathrm{ET}_{\mathrm{c}}$ were significantly affected by irrigation levels. The greatest WUE was in the 55\% treatment although not significantly different from the I80\% treatment plots. These results are similar to those reported by Colaizzi et al. (2004) in that grain sorghum irrigated at levels of $100 \%$ and $75 \%$ of ET produced yields that were not significantly different. The greatest IWUE occurred in the I55\% treatment plots, yet they were not significantly different than the I30\% treatment plots.

In 2010, biomass and dry grain yields were significantly greater in the highest irrigated treatment plots (80\% and 55\%) as compared with the deficit treatments of $30 \%$ and $0 \%$. Crop water use and WUE were significantly greater between irrigated $\left(\mathrm{I}_{80 \%}, \mathrm{I}_{55 \%}\right.$, and $\mathrm{I}_{30 \%}$ ) and non-irrigated plots $\left(\mathrm{I}_{0 \%}\right)$, but there were no significant differences among the irrigated treatment plots. The largest average yield increase for both sorghum varieties occurred between the $30 \%$ and $55 \%$ amount treatments, where the average yield 
increase was $2.4 \mathrm{Mg} \mathrm{ha}^{-1}$ in 2009 . These results are similar to findings reported by Schneider and Howell (1999) for grain sorghum irrigated between $25 \%$ and $50 \%$ of crop ET at Bushland, TX. Sorghum was less responsive in 2010 to different irrigation levels as compared to the previous year, i.e. crop water use and WUE was not significantly different between the three irrigation treatment levels ( $80 \%, 55 \%$, and $30 \%)$. The average increase in yield between the $30 \%$ and $55 \%$ treatment amounts was reduced by $45 \%$. Soil water levels were similar for these treatments through DOY 216 for both irrigation methods (Fig. 4).

\subsection{CWSI-TT and soil water depletion}

In 2009, regression analysis of the CWSI-TT and $D_{\mathrm{f}}$ revealed a significant relationship: CWSI-TT $=740.36 D_{\mathrm{f}}+118.06, r^{2}=0.34$, $F=14.71$, and $p<0.0001$. The CWSI-TT index declined after irrigations, as expected, and was nearly zero on cloudy days and days with precipitation (Fig. 5a). In the 2009 growing season, $D_{\mathrm{f}}$ was lowest on August 1 (DOY 213) after $32 \mathrm{~mm}$ of rainfall and increased to its greatest amount on August 8 (DOY 220), during the later vegetative stage. Soil waster depletion also rose after the onset of the reproductive stage (August 18, DOY 230) and during the nonirrigation period between September 12 and 21 (DOY 255 and 264) when no irrigation signals were triggered.

Early in 2010, DOY 196-198, during the vegetative phase, mean fractional soil water depletion was low (0.15), while the CWSI-TT index was at high levels, i.e. 550-800 min (Fig. 5b). As mentioned previously, this was likely due to the IRTs viewing soil background in addition to vegetative cover in the early portion of the irrigation season. Fractional soil water depletion increased at the reproductive stage (near flowering) from DOY 209 to 216 and then again prior to the soft dough stage. Variation of the CWSI-TT followed this pattern and was recorded as increasing from DOY 213 to 216. Between DOY 233 and DOY 238, as soil water depletion increased the CWSI-TT trended upwards but was also impacted by irrigations and rainfall. Late in the irrigation season from DOY 242 to 246, soil water depletion decreased, but the CWSI-TT remained high. This may be due to IRTs viewing heads of drying grain (with no transpiration) more so than transpiring canopy leaves. There was a significant relationship between the CWSI-TT and $D_{\mathrm{f}}$ in 2010 after DOY 210 and through DOY 254; CWSI-TT $=783.9 \times$ CWSI$\mathrm{TT}+139.4, r^{2}=0.22, F=6.5, p<0.02$. However, the relationship was not as strong as 2009, which may have been due to the smaller changes in $D_{\mathrm{f}}$ over the 2010 growing season.

Disadvantages to using the CWSI-TT was that cloud cover could reduce irrigation triggering at any time during the growing season, and IRT temperature readings could be influenced by changing crop aspect (e.g., leaf orientation and erectness, head formation) throughout the growing season. This problem motivates future research into multi-band sensor systems that may allow recognition of soil background and plant aspect changes that may allow corresponding qualification or correction of thermal IR data. Soil water sensors and soil water balance equations (estimated from $\mathrm{ET}_{\mathrm{o}}$ ) could be used to augment decisions for irrigation scheduling with the CWSI-TT and may be helpful in the case where it takes a pivot more than two days to traverse a field.

\section{Conclusions}

A theoretical CWSI index summed over daylight hours was investigated for its effectiveness as a trigger for automatic irrigation scheduling of two varieties of grain sorghum. Crop biomass and dry grain yield responses from the Automatic treatment plots compared well to those from manual scientific irrigation scheduling based on soil water content, in the highest irrigation treatment level $\left(\mathrm{I}_{80 \%}\right)$ in 2009 and in all irrigation treatment levels in 2010. Soil water variability early in growing season 2009 affected yield production, and may have affected the results at the two lower irrigation amounts $\left(\mathrm{I}_{50 \%}\right.$ and $\mathrm{I}_{30 \%}$ ). Automatic irrigations generally occurred every 2-4 days after the crop was past boot stage. The constant irrigation applications in the amount of twice peak daily crop water usage on a frequent basis with LEPA drag socks was a favorable method for irrigation delivery to both early and late maturing grain sorghum. A shortcoming of using the CWIS-TT, which is common to all thermal-based indices using radiometric sensors, is that false positive irrigation triggers may be generated early in the season, which could lead to over irrigation. Although soil water variability confounded some results in 2009, yields from the automatic $80 \%$ treatment plots (plots from which the CWSITT were calculated over daylight hours) were similar to scientific irrigation scheduling using a neutron probe in the manual $80 \%$ treatment plots for both years and for all treatment levels in 2010. This supports the use of the CWSI-TT as an effective method for irrigation scheduling of grain sorghum.

While farmers are not likely to use a neutron probe to take soil water measurements, they may invest in moving sprinkler systems that are outfitted with sensor networks for automated control and continuous plant water status feedback as a means to manage irrigation scheduling. Using the automated system would alleviate the additional time and expense required to drive to each pivot field and take soil water measurements on a weekly basis. Further research is necessary to investigate whether the CWSI-TT is effective for irrigation scheduling of other crops in this region and to determine which decision support methods would best augment plant feedback irrigation scheduling.

\section{Acknowledgments}

The authors appreciate the dedicated work performed by Brice Ruthardt, Biological Science Technician, and Luke Britten, Agricultural Science Technician, USDA-ARS, Conservation and Production Research Laboratory, Bushland, TX. Partial funding for this project was from the Ogallala Aquifer Program, a consortium between USDA-Agricultural Research Service, Kansas State University, Texas AgriLife Research, Texas AgriLife Extension Service, Texas Tech University, and West Texas A\&M University; and from the United Sorghum Checkoff Program (R0021-09 and R0012-10).

\section{References}

Ajayi, A.E., Olufayo, A.A., 2004. Evaluation of two temperature stress indices to estimate grain sorghum yield and evapotranspiration. Agron. J. 96, 1282-1287.

Allen, R.G., Pereira, L.S., Raes, D., Smith, M., 1998. Crop evapotranspiration - guidelines for computing crop water requirements. FAO Irrigation and Drainage Paper 56.

Barbosa da Silva, B., Rao, T.V., 2005. The CWSI variations of a cotton crop in a semiarid region of Northeast Brazil. J. Arid Environ. 62, 649-659.

Colaizzi, P.D., Schneider, A.D., Evett, S.R., Howell, T.A., 2004. Comparison of SDI, LEPA, and spray irrigation performance for grain sorghum. Trans. ASAE 47 (5), 1477-1492.

Colaizzi, P.D., Gowda, P.H., Marek, T.H., Porter, D.O., 2009. Irrigation in the Texas High Plains: a brief history and potential reductions in demand. Irrig. Drain. 58. (3), 257-274.

Emekli, Y., Bastug, R., Buyuktas, D., Emekli, N.Y., 2007. Evaluation of a crop water stress index for irrigation scheduling of bermuda grass. Agric. Water Manage. 90 (3), 205-212.

Evett, S.R., 2002. Water and energy balances at soil-plant-atmospheric interfaces. In: Warrick, A.W. (Ed.), The Soil Physics Companion. CRC Press, Boca Raton, FL, pp. 128-188.

Evett, S.R., 2008. Neutron moisture meters. In: Evett, S.R., Heng, L.K., Moutonnet, P., Nguyen, M.L. (Eds.), Field Estimation of Soil Water Content: A Practical Guide to Methods, Instrumentation, and Sensor Technology. IAEA-TCS-30. International Atomic Energy Agency, Vienna, Austria, pp. 39-54, Available at http://wwwpub.iaea.org/mtcd/publications/PubDetails.asp?pubId=7801, ISSN: 1018-5518 (Chapter 3).

Farahani, H.R., Slack, D.C., Kopec, D.M., Matthias, A.D., 1993. Crop water stress index models for Bermuda grass turf: a comparison. Agron. J. 85, 1210-1217. 
Garrot, D.J., Ottman, M.J., Fangmeier, D., Husman, S.H., 1994. Quantifying wheat water stress with the crop water stress index to schedule irrigations. Agron. J. 86, 195-199.

Gontia, N.K., Tiwari, K.N., 2008. Development of crop water stress index of wheat crop for scheduling irrigation using infrared thermometry. Agric. Water Manage. 95 (10), 1144-1152.

Hattendorf, M.J., Carlson, R.E., Halim, R.A., Buston, D.R., 1988. Crop water stress index and yield of water-deficit-stressed alfalfa. Agron. J. 80, 871-875.

Howell, T.A., Musick, J.T., Tolk, J.A., 1986. Canopy temperature of irrigated winter wheat. Trans. ASAE 29 (6), 1692-1699.

Howell, T.A., 2002. Irrigation efficiency. In: Lal, R. (Ed.), Encyclopedia of Soil Science. Marcel Dekker, Inc., New York, NY, pp. 736-741.

Jackson, R.D., Idso, S.B., Reginato, R.J., Pinter, P.J., 1981. Canopy temperature as a crop water stress indicator. Water Resour. Res. 17, 1133-1138.

Jackson, R.D., Kustas, W.P., Choudhury, B.J., 1988. A reexamination of the crop water stress index. Irrig. Sci. 9, 309-317.

Lyle, W.M., Bordovsky, J.P., 1983. LEPA irrigation system evaluation. Trans. ASAE 26 (3), 776-781

Mahan, J.R., Conaty, W., Neilson, J., Payton, P., Cox, S.B., 2010. Field performance in agricultural settings of a wireless temperature monitoring system based on a low-cost infrared sensor. Comput. Electron. Agric. 71, 176-181.

Möeller, M., Alchanatis, V., Cohen, Y., Meron, M., Tsipris, J., Naor, A., Ostrovsky, V., Sprintsin, M., Cohen, S., 2007. Use of thermal and visible imagery for estimating crop water status in irrigate grapevine. J. Exp. Botany 58 (4), 827-838.

Nielsen, D.C., 1990. Scheduling irrigations for soybeans with the Crop Water Stress Index. Field Crop Res. 23 (2), 103-116.

Olufayo, A.A., Baldy, C., Ruelle, P., 1996. Sorghum yield, water use and canopy temperatures under different levels of irrigation. Agric. Water Manage. 30, 77-90.

Or, D., Wraith, J.M., 2002. Soil water content and water potential relationships. In: Warrick, A.W. (Ed.), The Soil Physics Companion. CRC Press, Boca Raton, FL, pp. 49-84.
O’Shaughnessy, S.A., Evett, S.R., 2010. Developing wireless sensor networks for monitoring crop canopy temperature using a moving sprinkler system as a platform. Appl. Eng. Agric. 26 (2), 331-341.

O'Shaughnessy, S.A., Hebel, M.A., Evett, S.R., Colaizzi, P.D., 2011. Evaluation of a wireless infrared thermometer with a narrow field of view. Comput. Electron. Agric. 76, 59-68.

Peters, R.T., Evett, S.R., 2004. Modeling diurnal canopy temperature dynamics using one-time-of-day measurements and a reference temperature curve. Agron. J. 96, $1553-1561$.

Peters, R.T., Evett, S.R., 2007. Spatial and temporal analysis of crop stress using multiple canopy temperature maps created with an array of center-pivot-mounted infrared thermometers. Trans. ASABE 50 (3), 919-927.

Schneider, A.D., Howell, T.A., 1999. LEPA and spray irrigation for grain crops. J. Irrig. Drain. Eng. 125 (4), 167-172.

Soil Survey Staff, 2004. National Soil Survey Characterization Data. Soil Survey Laboratory, National Soil Survey Center, USDA-NRCS, Lincoln, NE (Verified: Friday, October 01, 2004).

Steiner, J.L., Howell, T.A., Schneider, A.D., 1991. Lysimetric evaluation of daily potential evapotranspiration models for grain sorghum. Agron. J. 83 (1), 240-247.

Throssel, C.S., Carrow, R.N., Milliken, G.A., 1987. Canopy temperature based irrigation scheduling indices for Kentucky Bluegrass turf. Crop Sci. 27 (1), 126-131.

Unger, P.W., Wiese, A.F., 1979. Managing irrigated winter wheat residues for water storage and subsequent dryland grain sorghum production. Soil Sci. Soc. Am. J. $43,582-588$.

Wanjura, D.F., Hatfield, J.L., Upchurch, D.R., 1990. Crop water stress index relationships with crop productivity. Irrig. Sci. 11, 93-99.

Yazar, A., Howell, T.A., Dusek, D.A., Copeland, K.S., 1999. Evaluation of crop water stress index for LEPA irrigated corn. Irrig. Sci. 18 (4), 171-180.

Yuan, G., Luo, Y., Sun, X., Tang, D., 2004. Evaluation of a crop water stress index for detecting water stress in winter wheat in the North China Plain. Agric. Water Manage. 64 (1), 29-40. 